\title{
Aoristo)))))
}

International Journal of Phenomenology, Hermeneutics and Metaphysics

\section{Poder e liberdade: a herança grega}

Power and freedom: the Greek heritage

Prof. Dr. Francisco Moraes

Universidade Federal Rural do Rio de Janeiro - UFRRJ'

\section{RESUMO}

Meu propósito no presente artigo é pensar o nexo entre poder e liberdade a partir de Tucídides e Aristóteles. No discurso fúnebre de Péricles em homenagem aos atenienses mortos em combate durante a Guerra do Peloponeso e na determinação da virtude ética da coragem, feita por Aristóteles em sua Ética a Nicômaco, encontra-se a mesma atitude ousada de consideração dos riscos inerentes à ação. É o que acontece no exercício reflexivo da deliberação. A herança grega consiste na visão de que o exercício do poder possui um caráter liberador. Ao contrário da dominação, o poder deixa livres aqueles que estão em sua órbita.

\section{PALAVRAS-CHAVE}

Poder; liberdade; secularização

\section{ABSTRACT}

My purpose in this paper is to think about the nexus between power and freedom from Thucydides and Aristotle. In Pericles' funeral speech in honor of the Athenians died in combat during the Peloponnesian War and in the determination of the ethical virtue of courage, made by Aristotle in his Nicomachean Ethics, there is the same bold atitude of considering the inherent risks of the action. That is what happens in the reflexive exercise of deliberation. The Greek heritage consists of the view that the exercise of power has a liberating feature. Unlike domination, power leaves free those in his orbit.

\section{KEY-WORDS}

Power; Freedom; Secularization

\footnotetext{
${ }^{1}$ E-mail: fjdmoraes@gmail.com Orcid: https://orcid.org/0000-0002-2166-8048
} 


\section{Aoristo)))))}

International Journal of Phenomenology, Hermeneutics and Metaphysics

\section{INTRODUÇÃO}

"Felicidade é liberdade e liberdade é coragem."

Tucídides

O nome próprio da liberdade é autodeterminação. É assim desde os gregos. Desde os gregos quer dizer algo bem concreto. Não se trata de uma opinião difundida por alguns filósofos e historiadores, e que, em seguida, tenha se tornado influente. A autodeterminação era a experiência política fundamental do cidadão grego. Não por acaso, essa experiência política traduzia-se numa grande independência das cidades-estados gregas entre si e em inúmeros confrontos entre elas. O mais célebre de todos esses confrontos ficou conhecido como a Guerra do Peloponeso, que opôs as duas cidades gregas mais poderosas e influentes: Esparta e Atenas e seus respectivos aliados. A guerra, como sabemos, foi vencida por Esparta, mas os valores triunfantes foram os valores atenienses. Na derrota, os atenienses obtiveram seu triunfo, pois marcaram decisivamente uma diferença, uma certa visão do que significa ser livre, que desde então tem se mantido decisiva para os povos do Ocidente.

Mas de que maneira a liberdade ateniense foi pensada? Que pressupostos ela mobilizou? Em que experiência fundamental ela se baseou? Nossa hipótese é a de que a liberdade como autodeterminação é fruto da secularização. Secularização não significa somente o que hoje entendemos por essa palavra, sob o signo do Iluminismo, ou seja, uma espécie de afastamento da influência tradicional e religiosa sobre a vida humana em seu conjunto, o predomínio cada vez maior da razão sobre a fé, a aposta no progresso da ciência e do bem-estar social, a independência do Estado de qualquer ingerência por parte da igreja, mas algo muito mais decisivo: a abertura do mundo, o tornar acessível do mundo. Sem esse tornar acessível do mundo, sem a liberdade concedida às coisas em sua totalidade, a liberdade humana como autodeterminação não seria possível. É o que se manifesta na universalidade, no universal. $\mathrm{O}$ universal exerce um fascínio e um poder mobilizadores que ultrapassam as particularidades. Um exemplo desse poder e desse fascínio é a chamada literatura universal. Trata-se, assim, de pensar a liberdade em conexão com o poder. Diferente da dominação, que, no limite, torna incompatíveis poder e liberdade, o poder político precisa deixar livres aqueles que se encontram em sua órbita². Quem reivindica

\footnotetext{
2 Evidentemente, "deixar livres" não equivale aqui à prepotência do "tornar livres", justificativa típica do imperialismo atual para realizar sua política de dominação em escala planetária e expandir os seus interesses econômicos. Outra questão seria a de se perguntar se os próprios atenienses se mantiveram fiéis à sua forma política de considerar o poder. O destino dos mélios (HGP, V, 84 ss), apresentado em suas minúcias por Tucídides, parece indicar que isso, de fato, não ocorreu. De todo modo, continua válido dizer que "o poder não é o oposto da liberdade. É justamente a liberdade que diferencia o poder da violência ou da coerção." (HAN, 2019, p. 23)
} 


\section{Aoristo)))))}

\section{International Journal of Phenomenology, Hermeneutics and Metaphysics}

autoridade é que já não a possui ${ }^{3}$. Esta é a herança grega: um imperativo de liberdade. A conexão entre poder e liberdade, a herança grega, será abordada mediante o comentário de um texto célebre, o discurso fúnebre de Péricles, pronunciado em homenagem aos atenienses que tombaram em combate no início da Guerra do Peloponeso e que chegou até nós por intermédio do historiador Tucídides ${ }^{4}$. Juntamente com o comentário desse texto, pretendo avaliar em que medida a filosofia ela própria pode ser entendida como resultado e expressão da própria secularização, algo que se pode perceber, de maneira mais próxima, no ideal de objetividade científica e em sua exigência de imparcialidade. Trata-se de expor a origem política da própria filosofia, de uma maneira um pouco diferente daquela apresentada pelo historiador Jean-Pierre Vernant ${ }^{5}$ em sua obra: Origens do pensamento grego. Em Platão e Aristóteles, mas já antes, entre os chamados pré-socráticos, a filosofia corresponde ao empenho de liberar o próprio espaço de auto-constituição humano, para além de tradicionalismos e particularismos. Este percurso encontra na Ética a Nicômaco de Aristóteles seu pleno acabamento. Por esse motivo, após o comentário do discurso fúnebre de Péricles, trataremos da delimitação da ação humana empreendida por Aristóteles.

Como bem mostrou Hannah Arendt, ao contrário dos instrumentos de violência, o poder não pode ser armazenado. O poder só existe enquanto é efetivado. Neste sentido, o poder guarda sempre a característica de ser potência (dýnamis, potentia, Macht, que provêm de mögen e möglich, e não de machen). Se a condição para a sua efetivação é que os homens se encontrem reunidos em relações de proximidade, sua realidade depende de que haja concórdia e entendimento entre eles, para além da mera cooperação do trabalho. É preciso que as palavras e os atos não se divorciem, que as palavras não sejam vazias e que os atos não sejam brutais, que as palavras não sejam empregadas para velar intenções, mas para revelar realidades, que os atos não sejam usados para violar e destruir, mas para criar relações e novas realidades. (ARENDT, 2009, p. 212) É um fenômeno crucial entender de que modo foi possível no Ocidente a desvalorização da vita activa juntamente com a depreciação do poder após um breve período de glorificação da ação e da política, que a autora de A Condição humana acredita ter existido, de modo exemplar, precisamente no tempo de Péricles e da democracia ateniense. Similar à acusação de Nietzsche de que a tragédia ática morreu de morte violenta, para Hannah Arendt a chamada vita activa teria sido destronada do palco da história graças ao ataque bemsucedido que lhe foi desferido por Platão e pelo platonismo, o qual fez emergir como

\footnotetext{
3 "Quem leva a efeito medidas, manifestações e ações conscientes, a fim de adquirir autoridade, quer, no fundo, poder e está a caminho do exercício autoritário do poder. Quem tem de recorrer à autoridade, como o pai na família ou o professor na sala de aula, não possui nenhuma autoridade. (GADAMER, 2011, p.124)

${ }^{4}$ A obra de Tucídides História da guerra do Peloponeso será doravante citada com a abreviação HGP.

${ }^{5}$ Para Vernant, a filosofia surge de um processo progressivo de valorização da palavra como instrumento de poder, que coincide com o aparecimento e o desenvolvimento da pólis. Um segundo aspecto importante relevado por Vernant é publicidade dada às manifestações mais importantes da vida social. "Pode mesmo dizer-se que a pólis existe apenas na medida em que surgiu um domínio público nos dois sentidos (diferentes, mas solidários) do termo: um setor de interesse comum, opondo-se às questões privadas; atuações abertas e transparentes, opondo-se aos processos secretos." (VERNANT, 1987, p. 57)
} 
International Journal of Phenomenology, Hermeneutics and Metaphysics

paradigma da vida humana a vita contemplativa. Ainda assim, em acordo com a intenção deste artigo, Arendt não deixa de reconhecer que precisamente a filosofia política de Aristóteles foi capaz de captar e elaborar conceitualmente o que há de central na experiência política grega (ateniense) em sua noção de enérgeia.

Esta insistência no ato vivo e na palavra falada como as maiores realizações de que os seres humanos são capazes foi conceituada na noção aristotélica de enérgeia (efetividade), com a qual se designavam todas as atividades que não visam um fim (que são ateleis) e não resultam numa obra acabada (não deixam par'autas erga), atividades que esgotam todo o seu significado no próprio desempenho. É da experiência dessa total efetividade que advém o significado original da paradoxal ideia do "fim em si mesmo"; pois, nesses casos de ação e discurso, não se busca um fim (telos), mas este reside na própria atividade que, assim, se converte em entelecheia, e a obra não sucede e extingue o processo, mas está contida nele; o desempenho é a obra, é enérgeia. Em sua filosofia política, Aristóteles tem ainda clara consciência do que está em jogo na política, ou seja, nada menos que o ergon tou anthropou ("a obra do homem" enquanto homem); e, se definiu essa obra como "viver bem" (eu zen), queria com isto dizer claramente que a "obra", neste caso, não é produto do trabalho, mas só existe na pura efetividade da ação. ${ }^{6}$

\section{DISCURSO FÚNEBRE DE PÉRICLES}

No discurso fúnebre, verdadeira instituição da polis democrática7, tratava-se, precisamente, de exaltar o valor de um modo de vida que se apresentava como digno de admiração em si mesmo, tanto pelas gerações atuais quanto pelas gerações vindouras. Começarei por uma passagem do referido discurso fúnebre que tem a marca de uma exaltação à política imperialista ateniense sob a liderança de Péricles. A despeito daquilo que ela certamente representa como elogio de uma política de

\footnotetext{
${ }^{6}$ apud., p. 218-219.

${ }^{7}$ Nicole Loraux chama a atenção, criticamente, para a situação desconcertante, do ponto de vista do historiador contemporâneo, de que "todos os epitáphioi apresentam, com diferentes gradações, a anomalia, que consiste em definir a democracia com traços não-democráticos." (1994, p. 193) Loraux recorre a duas passagens do discurso fúnebre para atestar o caráter aristocrático do elogio à democracia ateniense: a menção às leis não escritas, ágraphoi nómoi, que, segundo Péricles, "comportam a sanção de uma indiscutível desonra" (HGP, II, 37, 3) e o veredito segundo o qual "não é tanto o fato de pertencer a uma categoria, mas o mérito, que dá acesso às honrarias; inversamente, a pobreza não é razão para que um homem, capaz, em todo caso, de prestar serviços ao Estado, seja impedido de fazê-lo pela obscuridade de sua condição." (HGP, II, 37, 1) É que para a autora as leis não escritas remetem ao pudor (aidós) e à desonra (aiskhýne), valores típicos da antiga moral aristocrática; por outro lado, ao destacar o mérito como critério de acesso às honrarias, Péricles procura distinguir a areté de seu homônimo oligárquico, que se confunde com a situação de nascimento ou com a fortuna. Desse modo, "negando os critérios sociais que fundamentam os regimes oligárquicos, a democracia torna-se, então, o refúgio do puro princípio aristocrático." (LORAUX , 1994, p. 202) Mas exatamente essa aristocratização da democracia, ao nosso ver, representa o aspecto monumental do empreendimento político ateniense, que se tornou paradigmático desde então.
} 


\section{Aoristo)))))}

\section{International Journal of Phenomenology, Hermeneutics and Metaphysics}

poder, que deve ser nuançada pela consciência da derrota de Atenas ${ }^{8}$, há na passagem alguns traços essenciais do que estou chamando de secularização. Vamos à passagem:

Existem marcas insignes, e não faltam testemunhos que indiquem esse poder e que nos ofereçam à admiração de todos, no presente e no futuro; não precisamos nem de um Homero para nos glorificar, nem de ninguém cujas ênfases fascinarão no momento, mas cujas interpretações terão de sofrer as consequências da verdade dos fatos: constrangemos todo mar e toda terra a abrir-se diante de nossa audácia e em todos os lugares deixamos monumentos imortais, recordações dos males e dos bens 9 .

A secularização comparece na passagem visivelmente no apego à verdade dos fatos (érga), em contraste com a glorificação poética de um Homero, que não seria capaz de resistir à primeira. A poesia é assim destronada em sua capacidade de imortalizar os feitos, pois os feitos, as obras, falam por si mesmos. Tais feitos tornamse "marcas insignes", "monumentos imortais", e revelam males e bens como algo memorável, mas despidos de todo adorno e exagero. A secularização reflete uma não necessidade de ênfase, a qual apenas despertaria um fascínio momentâneo, em virtude precisamente da confiança nos feitos realizados. São estes os únicos que são dignos de memória, livres da necessidade de glorificação do poeta. Mas qual teria sido a obra dos atenienses que, afinal, os recomendaria à admiração de todos, no presente e no futuro? Péricles declara sem rodeios: "constrangemos todo mar e toda terra a abrir-se diante de nossa audácia". A palavra grega aqui em destaque é tolmé: audácia. A audácia corresponde a uma postura, a uma atitude, que não recua diante de nada. Se a medida do divino é o temor reverente, a audácia política implica em postar-se, despreocupadamente, diante do perigo. A secularização é o aspecto das coisas quando estas são tornadas acessíveis (genésthai esbatòn) por meio ou diante da audácia $^{10}$. O que se torna acessível são as coisas em sua totalidade para um uso possível. Não há nada, em princípio, que não possa ser acessado. $O$ uso pode negligenciar a proveniência e assenhorar-se das coisas sem maiores cuidados e precauções. No uso há sempre, em maior ou menor grau, expropriação. Ele deixa as coisas livres e abre novas possibilidades. O uso que um morador faz de sua casa, que se manifesta para e pelo uso (tà eis chrêsin phanerá) ${ }^{11}$, não pode ser regulado previamente por nenhum construtor enquanto construtor. $\mathrm{O}$ que se manifesta por e para um uso é sempre algo que somente o uso pode descobrir. A casa só é casa à medida que é habitável. Ater-se a esse caráter de uso de todas as coisas como o seu caráter decisivo, como sua instância última de manifestação, é o que caracteriza a audácia ateniense. Mas essa postura "esclarecida", que encontra no uso aquilo que a coisa realmente é, implica em ter de abandonar a atitude mais segura e tradicional de

\footnotetext{
${ }^{8}$ Ou seja, Tucídides não está simplesmente referendando as palavras de Péricles.

${ }^{9} \mathrm{HGP}, \mathrm{II}, 41,4$.

${ }^{10}$ HGP, II, 41, 4.

${ }^{11}$ HGP, II, 62, 2.
} 


\section{Aoristo)))))}

International Journal of Phenomenology, Hermeneutics and Metaphysics

uma diferença assegurada e claramente demarcável entre o que é próprio, autóctone, nacional, e o que é estrangeiro, estranho, distante. Trata-se de deixar chegar literalmente todas as coisas à proximidade do uso. Haveria assim uma indiferença entre o que é próprio e o que é estranho, uma indiferença que pode estar na raiz do que entendemos por objetividade científica. "Vemos chegar até nós, graças à importância de nossa cidade, todos os produtos de toda a terra, e os bens fornecidos por nosso país não são mais nossos, para nosso usufruto, que os do resto do mundo"12.

É por ousar alcançar o que ainda não está disponível, o que não é patrimônio fixo e tradicional, que o ateniense de Péricles e Tucídides reivindica para si a admiração dos homens. Esta é a contraparte da política de poder, do imperialismo ateniense. $\mathrm{O}$ ateniense está, literalmente, pronto para tudo. A mesma postura pode ser encontrada no historiador Tucídides. O exame crítico do próprio passado nada mais significa que torná-lo acessível. É preciso correr o risco da confrontação com os fatos. O espartano, ao contrário, dedica-se a preservar o que já tem, assim como os homens em geral, por falta de ousadia, inclinam-se de preferência para a versão corrente e disponível (tà hetoîma) em vez de saírem em busca da verdade ${ }^{13}$. Esta é a apreciação crítica feita pelos coríntios, diante dos próprios espartanos reunidos em assembleia: "[...] os atenienses são resolutos e vós hesitantes; dispostos a deixar a sua terra e vós, apegadíssimos à vossa, pois eles julgam que da ausência tirarão proveito e vós, que com o partir prejudicareis até o que já tendes à disposição (tà hetoîma)"14. Por isso, é perfeitamente possível dizer que "a relação dos homens com seu passado é espontaneamente "espartana". A atitude de Tucídides, pelo contrário, é resolutamente "ateniense"."(BRAGUE, 2007, p. 43)

A secularização implica o desprendimento diante do que já está posto e disponível, o risco de ausentar-se e expor-se. É preciso deixar a segurança da casa, o conforto das ideias fixas e preconcebidas, da tradição consolidada. Ao desdenhar Homero, o Péricles de Tucídides não deixa de repercutir e referendar o exemplo de Ulisses, que se torna até mesmo paradigmático. Mas quem se ausenta ousadamente só o faz em vista do possível. Os atenienses foram admiráveis porque tornaram acessíveis todas as coisas enquanto possíveis. A secularização significa assim a abertura decidida ao que é possível. E este nunca está dado. Sua natureza implica a própria possibilidade do fracasso, ou seja, o risco. A liberdade implica em abrir-se ao possível, o qual, por sua vez, implica em expor-se ao perigo. O possível só é visível à luz do perigo. Por isso, não pode haver liberdade sem coragem e ousadia. Mas se tentar o possível significa ir além do que é simplesmente real, do que está simplesmente dado, este não significa a negação do próprio real. Negando o real apenas ganhamos o irreal, o imaginado, o fantasiado. O possível só é possível no próprio real, como o que ousadamente se escava nele.

\footnotetext{
12 HGP, II, 38, 2.

${ }^{13}$ Houtos atalaíporos toîs polloîs he zétesis tês aletheía kaì epì tà hetoîma mâllon trépontai. (HGP, I, 20, 3)

${ }^{14}$ HGP, I, 70, 4.
} 


\section{Aoristo)))))}

International Journal of Phenomenology, Hermeneutics and Metaphysics

Como visto, o possível designa o futuro aberto como tal a uma decisão humana. A ousadia é a decisão de não permitir que este se descole do presente e se torne miragem utópica ou que se encerre em si mesmo de modo a permitir a atividade tranquilizadora no presente. A ousadia é a atitude de deixar que as coisas se apresentem enquanto possíveis desde sua própria realidade presente. Sem tal coragem prévia, que assume o perigo supremo da exposição, a liberdade de escolha se reduziria a algo pueril. As belas coisas possíveis, as grandes coisas tornadas acessíveis ao homem, só se oferecem a quem está disposto a arriscar-se por elas. O que se oferece como objeto de empenho e dedicação amorosa possui sempre a marca do possível. O possível não é, portanto, o que descobrimos ao lado da realidade e em subordinação a ela: o que ainda não se tornou real, o que ainda não se realizou, mas está disponível e é manipulável. As grandes coisas nunca se deixam realizar integralmente segundo nossos critérios e expectativas. O que pode ser esgotado e realizado é sempre o que dispensa a ousadia e carece apenas de aplicação metódica. É o possível degradado em realizável e negociável. Mas o possível enquanto tal continua possível mesmo depois de realizado. Daí o risco, o perigo que ele comporta. Quando tentamos o possível o fracasso também se avizinha, ele ameaça. E não se trata de fracassar nisso ou naquilo, mas pura e simplesmente de fracassar. Mas há um outro lado também, um outro lado surpreendente. É que quem assume o fracasso, quem enfrenta essa ameaça, está literalmente posto em si mesmo, está pronto para tudo e já não tem propriamente o que temer, pois o possível supera o que está simplesmente dado. O ser livre é assim um ser posto em si mesmo, um contar sobretudo consigo mesmo, um não basear-se em nada alheio, em nada que fundamente a liberdade. A liberdade se revela como bela despreocupação (rhathimía), como exposição resoluta e confiante, que se alegra quando se arrisca, que só dispõe propriamente do perigo como abertura ao possível.

Péricles, em seu discurso, menciona alguns traços marcantes da liberdade característica do modo de viver ateniense, todos eles conectados à ousadia diante do possível. O primeiro traço é o que hoje chamamos de liberalidade. Trata-se de uma maneira de conduzir-se que não se imiscui na vida privada do cidadão. Este é deixado livre para viver como bem entender sem tornar-se, por isso, objeto de vigilância e de censura ${ }^{15}$. O segundo traço menciona uma superioridade na preparação para a guerra. Esta adviria menos de preparativos constantes do que da confiança demonstrada no momento de agir. A coragem resulta antes da maneira de viver do que da compulsão das leis. Os atenienses não se perturbam antecipando desgraças ainda não existentes, mas na hora de agir demonstram tanta bravura quanto aqueles que estão sempre sofrendo ${ }^{16}$. O terceiro traço se apresenta na ocupação com as atividades públicas. O homem alheio às atividades públicas é visto como alguém que cuida apenas de seus interesses, mas como um homem perfeitamente inútil. Os atenienses decidem por si mesmos as questões públicas na crença de que não é o debate que é empecilho para a ação, mas o fato de não se estar esclarecido

\footnotetext{
${ }^{15}$ HGP, II, 37.

${ }^{16}$ HGP, II, 39.
}

Poder e liberdade: a herança grega 


\section{Aoristo)))))}

International Journal of Phenomenology, Hermeneutics and Metaphysics

antes de chegar a hora da ação. Eles são ousados para agir, mas gostam de refletir sobre os riscos que pretendem correr. Para os outros, porém, ousadia significa ignorância e reflexão traz hesitação ${ }^{17}$. O quarto traço diz respeito à forma de estabelecer amizade e de formar amigos. Os atenienses, no dizer de Péricles, adquirem amigos não por receberem favores, mas por fazê-los. E isso não por algum cálculo de vantagens a receber, mas pela confiança inerente à liberdade ${ }^{18}$. Por fim, de acordo com o quinto traço, cada homem ateniense poderia mostrar-se autossuficiente nas mais variadas formas de atividade e isso com a maior elegância e naturalidade ${ }^{19}$.

Todos os traços mencionados são modos de deixar, modos de ousadia. Deixa-se cada um viver por sua conta (liberalidade); deixa-se as preocupações com as desgraças ainda não existentes (confiança no presente, modo de viver); deixa-se a casa para dedicar-se às atividades públicas (vida política); deixa-se o perigo apresentar-se como perigo (exercício deliberativo); deixa-se o favorecido ser livre para retribuir ou não o favor (magnanimidade, amizade ativa); e deixa-se o apego a qualquer forma de especialização inerte e limitadora (versatilidade). Cada traço da liberdade acima mencionado corresponde a uma forma de confiança e ousadia envolvendo a abertura ao possível e o risco a ele inerente. Em maior ou menor grau refletem o estar em si mesmo, o contar consigo mesmo, típicos da autossuficiência do homem livre. Por maior que seja a idealização aqui empregada, que muitas vezes parece chocar-se com a realidade e a crueza do imperialismo, devemos estar atentos ao ideal que nela é afirmado. Nele se exprime um tipo de vida que superou a adesão ao tradicionalismo, uma vida que se lança ousadamente no espaço livre do possível, pois o uso deixa livre o que é usado.

\section{AÇÃO E VIRTUDE EM ARISTÓTELES}

Do ponto de vista grego, a inteligibilidade da ação praticada, seu valor propriamente dito, não reside nos efeitos (utilitarismo moral), mas no caráter do agente. A ação é significativa na medida em que revela virtude ou vício. As virtudes são disposições louváveis e os vícios disposições censuráveis. Numa ação, segundo Aristóteles, o que importa antes de tudo é saber se podemos reconhecer nela certa disposição de agir segundo a razão (de forma deliberada), com constância, em vista do bem factível que é escolhido por si mesmo, ou seja, a virtude ${ }^{20}$. A ação deve revelar essa disposição do agente. Isso significa assumir que o resultado da ação possui algo de não inteiramente controlável, de não inteiramente previsível, de intrinsecamente obscuro, e que podemos nos aproximar mais ou menos do fim proposto. Podemos contar apenas com o que está em nosso poder. Podemos confiar que agiremos de certa maneira, tão logo dada situação se apresente, mas não podemos estar seguros de que ela se apresentará ou de que a ação terá o efeito

\footnotetext{
${ }^{17} \mathrm{HGP}, \mathrm{II}, 40$.

${ }^{18} \mathrm{HGP}, \mathrm{II}, 40$.

${ }^{19}$ HGP, II, 41.

${ }^{20}$ Ética a Nicômaco, II,2, 1104 b 30.
} 


\section{Aoristo)))))}

\section{International Journal of Phenomenology, Hermeneutics and Metaphysics}

esperado. Por outro lado, a atenção dirigida ao caráter do agente não permite que o resultado da ação seja avaliado isoladamente, de acordo com a medida ordinária, ou seja, levando-se em conta o cálculo do benefício e do prejuízo. Até temos como julgar que algumas ações ou paixões são intrinsecamente condenáveis, graças à sua vileza intrínseca ${ }^{21}$, mas nunca poderemos estabelecer que uma ação, por mais que traga consequências benéficas, seja intrinsecamente louvável, da mesma forma que não pode ser considerada má uma ação que acarrete sofrimento, seja para o próprio agente seja para os demais envolvidos. O que salva uma ação reside na disposição do agente e mais em nenhuma outra parte, à medida que os homens são constantemente estimulados a produzir o que é grande e luminoso (tà megála kaì lamprá) ${ }^{22}$. Na disposição assim compreendida se encontra o verdadeiramente salutar, o intrinsecamente louvável, o bem.

A literatura universal, a grande literatura, conhece perfeitamente esse estado de coisas. Seu objetivo nunca é louvar ou censurar determinadas ações ou sentimentos em virtude de seus efeitos, como se a inveja, o assassinato, o roubo, fossem nefastos por trazerem danos aos outros e ao próprio agente, quando este é descoberto, ou como se a caridade ou a liberalidade fossem benéficas por seus resultados e, por isso, merecedoras de louvor. O que importa é trazer à luz o caráter de um personagem por meio de suas ações. Vejamos o caso de $O$ velho e o mar, de Hemingway. Trata-se de um humilíssimo pescador: Santiago. Está há 84 dias sem pescar e já era considerado salao, ou seja, azarado da pior espécie. Tinha um ajudante, um jovem a quem ensinara a pescar e que o adorava. Mas, em virtude da má sorte, os pais do jovem exigiram que este mudasse de barco. Estava então Santiago sozinho, velho, desmoralizado quando se lança ao mar. Neste dia, porém, fisga um peixe desproporcionalmente grande. Um marlim maior do que seu próprio barco, com mais de cinco metros de cumprimento, que o arrasta para o alto mar. Santiago não hesita por um instante sequer. Sabia que deveria fazer todo o possível, tudo o que estivesse ao seu alcance, para matar o enorme peixe. E assim o fez ao logo de uma luta que durou três dias, sob tremendas privações e sofrimentos. Ao fim e ao cabo, quando consegue matar o enorme peixe, de quem se considera amigo e irmão, os tubarões aparecem e devoram toda a valiosa carne do pescado. Sobra ao pescador derrotado o esqueleto do peixe atado ao barco e um esgotamento tal que por pouco não lhe custa a própria vida. Do ponto de vista do senso comum, todo o seu esforço foi inútil. Mas e do ponto de vista da literatura? O que emerge da história? Emerge um homem orgulhoso, cônscio de seu poder e da grandeza de seu ofício, um homem que arrisca a própria vida, que não se subordina ao útil. Ele deseja matar o peixe a quem considera seu amigo e irmão. Aqui está o seu valor, todo o seu caráter. Matar um peixe? Que valor intrínseco pode haver neste ato? Não há milhares de maneiras mais simples de atingir o mesmo objetivo, sem que isso implique em tamanhas

\footnotetext{
${ }^{21}$ Entre as ações e as emoções consideradas vis em si mesmas, Aristóteles menciona a inveja, a impudicícia, o adultério, o roubo e o assassinato. Ética a Nicômaco, II, 6, 1107 a 10.

${ }^{22}$ Hannah Arendt (apud.,p.218), que cita as palavras de Demócrito (Frag. B157), as complementa da seguinte forma: "enquanto existir a polis a inspirar os homens a ousarem o extraordinário, tudo estará seguro; se sucumbir, tudo estará perdido."
} 


\section{Aoristo)))))}

\section{International Journal of Phenomenology, Hermeneutics and Metaphysics}

provações e sofrimentos, sem que isso envolva esse tipo de heroísmo fantasioso? Esquecemos do desejo. Esquecemos que um dia um homem teve de querer matar para viver. O pescador deve desejar sua obra. E por esta obra deve estar disposto a correr os maiores riscos, do contrário não será digno de seu ofício. A grandeza do pescador está em desejar e não desistir de sua obra, de sua tarefa. Matar um peixe, quando a ocasião se apresenta, pode ser questão de vida ou morte. É o que a obra literária apresenta. O caráter amistoso e resoluto do pescador Santiago, sua grandeza humana, que o torna inclusive temível, é o que resulta do romance, desde o ponto de vista da literatura. Matar um peixe pode ser afinal muito mais do que simplesmente matar um peixe. O ofício do homem, e não apenas do pescador, é ter de matar o que ama. Aí está o seu valor, aí está a sua coragem. O que amamos, mais do que qualquer coisa dada, é o possível. O possível é o que possibilita a nossa ação, é o peixe que precisamos pescar. É do possível que precisamos dar cabo, que precisamos realizar de algum modo, para virmos a ser quem somos. Somos todos assassinos da pior espécie.

De forma muito similar, a visão filosófica da existência humana apresentada por Aristóteles na Ética a Nicômaco evidencia a necessidade da ação em aliança estreita e indissolúvel com o perigo do possível. Não temos tempo de percorrer todas as etapas, todos os elementos do empreendimento aristotélico de apresentar o homem como "princípio de suas ações" 23. No entanto, cabe demonstrar, em conformidade com o intento inicial deste trabalho, de que maneira a própria filosofia, aqui entendida como filosofia prática, fundamenta a felicidade na liberdade e esta última na coragem. Se a felicidade reside na ação e esta, por sua vez, não dispõe antecipadamente de suas condições de possibilidade, o projeto de autorrealização humano passa por ter de assumir o estar entregue a si mesmo do agente, ou seja, sua fragilidade. Só isso cabe chamar propriamente de coragem. É preciso liberar o homem para a sua constitutiva fragilidade, de modo a possibilitar seu estar em si mesmo, seu ser decidido, e somente por essa via seu pleno florescimento.

A articulação entre a ação e o caráter contingente do que podemos realizar ou esperar é, sem dúvida, algo manifesto e um aspecto fundamental da reflexão ética de Aristóteles. A importância da contingência é tão decisiva que um célebre comentador chegou a falar de uma ontologia da contingência em Aristóteles ${ }^{24}$. De fato, a prudência e a arte dizem respeito ao que pode ser de outro modo, ao que pode ser ou não ser, dependendo de uma decisão humana, da proaíresis. Afinal, nenhum homem sensato põe-se a deliberar sobre o que não pode ser de outro modo, sobre os objetos eternos como o Universo ou a diagonal, se a Terra é plana ou esférica, sobre o que se engendra sempre do mesmo modo (órbitas e o nascer dos astros), ou sobre o que se engendra ora de um modo ora de outro, como secas e chuvas, ou mesmo sobre as coisas que acontecem por acaso (descobrimento de um tesouro). Tampouco se

\footnotetext{
${ }^{23} \mathrm{EN}, \mathrm{III}, 5,1112$ b 32.

${ }^{24}$ AUBENQUE, 2002, p.65.
} 


\section{Aoristo)))))}

\section{International Journal of Phenomenology, Hermeneutics and Metaphysics}

delibera sobre todos os assuntos humanos ${ }^{25}$. "Delibermos sobre as coisas que estão em nosso poder, i.e., que podem ser feitas" 26 . O campo da ação é assim o campo no interior do qual podemos deliberar, o campo que envolve o possível. Mas o possível não está sendo caracterizado como o que pode ou não ocorrer. $\mathrm{O}$ acaso, alguns fenômenos naturais, e mesmo os assuntos humanos em geral não passam por nosso poder agir. Melhor dizendo, sobre eles não temos poder algum. Possível, portanto, é o que depende de nós, aquilo a respeito de que podemos dizer sim ou não, aquilo que mobiliza uma certa ação. O possível é o propriamente possibilitador da ação e não o simples fato de que ela possa ou não verificar-se. O possível remete à urgência de uma ação a ser praticada num dado contexto. Fora do possível não pode haver liberdade, pois não haveria como decidir-se e ser decidido. Mas diversamente do que ocorre no saber técnico, que sempre dispõe de parâmetros e procedimentos seguros, no caso da ação e da deliberação estamos diante da obscuridade do futuro. O agente é lançado sobre si e precisa decidir-se ele mesmo. Por isso, por vezes, pede conselhos, pois sabe dos riscos que corre. O melhor que pode fazer é confiar em sua insegurança. Esta não é casual ou superável mediante a experiência, mas constitutiva. O prudente, portanto, será sempre hesitante; não no sentido de evitar os perigos, mas pela coragem de hesitar, pela coragem de assumir os riscos, de ousadamente considerá-los. A coragem de agir seria impossível sem a coragem de hesitar diante do possível.

O virtuoso, e somente ele, está propriamente em risco, pois sabe que existe algo verdadeiramente nobre e digno em jogo na ação. Quem não se importa com a própria vida, por tê-la em pouca conta, não pode ser dito corajoso (como o mercenário), ainda que seja ele o melhor soldado na situação específica da guerra27. Assim sendo, se não há felicidade sem virtude, tampouco a virtude ou o ser virtuoso coincide com a felicidade. Há sempre condições que não escolhemos, infortúnios, que se abatem sobre nós e podem tornar a vida indigna de ser vivida. A virtude é a vida para a felicidade, mas não a sua garantia.

Assim como o Péricles de Tucídides, também Aristóteles observa a vida humana em virtude de sua fragilidade constitutiva. A liberdade é inseparável do perigo, pois é possibilitada pelo possível, pelo que depende de nós. Mas em vez de recuar diante da constitutiva insegurança do viver, em vez de defender o abandono desse espaço de hesitação, Aristóteles, tal como Péricles, aposta na necessidade da ação como condição para a felicidade. O risco deve ser assumido e enfrentado pela disposição ousada da deliberação. Somente os pouco valorosos acham que a ação seria melhor realizada sem hesitação. É o que verificamos na seguinte passagem do livro I da Ética a Nicômaco:

Da mesma forma que nos jogos Olímpicos os coroados não são os homens mais fortes e belos, e sim os que competem (pois alguns

\footnotetext{
${ }^{25} \mathrm{EN}, \mathrm{III}, 5,1112$ a $18 \mathrm{ss}$.

${ }^{26} \mathrm{EN}, \mathrm{III}, 5,1112$ a 31.

${ }^{27}$ É a conclusão a que chega Aristóteles na análise da virtude ética da coragem. EN, III, 8, 1116 b 3-24.
} 


\section{Aoristo)))))}

International Journal of Phenomenology, Hermeneutics and Metaphysics

destes serão vitoriosos), os que agem corretamente conquistam as coisas boas da vida. ${ }^{28}$

\section{CONSIDERAÇÕES FINAIS}

A herança grega, a saber: o nexo estrutural entre poder e liberdade, que buscamos recuperar a partir do comentário do discurso fúnebre de Péricles e da Ética a Nicômaco, de Aristóteles, nos encaminhou a duas atitudes aparentemente distintas: a ousadia e a hesitação prudente. Trata-se, na verdade, da mesma atitude, que se fundamenta na abertura diante do possível, do que não está disponível, atitude que assume o risco e o perigo da exposição na deliberação. Péricles acentua que a diferença fundamental do ateniense em relação ao espartano estava no gosto de deliberar, de refletir e encarar de frente os perigos, assumindo que a reflexão não constitui nenhum óbice para a ação ${ }^{29}$; Aristóteles, por sua vez, coloca a felicidade numa relação direta e estrutural com a virtude, demonstrando que esta última se baseia na coragem de hesitar diante do possível, ou seja, na deliberação. A hesitação prudente, ao contrário do que se acredita comumente, é a melhor tradução da ousadia ateniense, sua expressão mais fiel e acabada. A meu ver, na filosofia contemporânea, a obra que melhor acentua a mencionada herança grega é a obra do filósofo alemão Martin Heidegger. No escrito Da essência da verdade, Heidegger acentua um sentido prático da verdade que a retira de seu espaço tradicional de consideração vinculado à teoria do conhecimento. $\mathrm{O}$ escrito tem origem em uma conferência de 1930, que foi proferida, por diversas vezes; o texto foi publicado somente em 1943. Da essência da verdade marca o que se convencionou chamar de virada no pensamento heideggeriano. O que constitui o cerne desse escrito é a determinação da liberdade como a essência da verdade. A verdade, para Heidegger, não tem sua sede no enunciado representador, na proposição, e sim naquilo que ele chama de comportamento aberto. A verdade não se deixa encapsular ou armazenar no enunciado, entendido como coisa dada e disponível. A liberdade, como essência da verdade, aponta para o ser junto às coisas enquanto estas se apresentam para um comportamento que acolhe uma medida. A liberdade nunca é um fato constatável ou uma propriedade do homem. O comportamento aberto que acolhe uma medida, se submete a um comando que faculta ao homem, a cada vez concretizado, suas possibilidades mais próprias de ação e decisão. Liberdade e arbitrariedade se excluem reciprocamente, muito embora a realidade da liberdade exija a manifestação do poder: visibilidade. Nesse sentido, somente o poderoso, que acolhe o que se manifesta no seio do comportamento aberto, que assume a sua fragilidade constitutiva, seu ser exposto, é verdadeiramente livre e está, literalmente, pronto para tudo: livre para a morte. A liberdade como autodeterminação se concretizaria, paradoxalmente, como submissão a um tal comando, o que Heidegger denominou

\footnotetext{
${ }^{28} \mathrm{EN}, \mathrm{I}, 8,1099$ a $4-7$.

${ }^{29}$ HGP, II, 40.
}

Francisco Moraes

Toledo, v. 4, n・1 (2021) p. 78 91 


\section{Aoristo)))))}

\section{International Journal of Phenomenology, Hermeneutics and Metaphysics}

de sein lassen: deixar ser. Não se trata, para Heidegger, de subserviência, de rebaixamento a um ente qualquer, mas de uma entrega confiante ao caráter de ser desvelado que "se desdobra em um recuo diante do ente, a fim de que este se manifeste naquilo que é e como é, de tal modo que a adequação representativa dele receba a medida." (HEIDEGGER, 2008, p. 201) Para compreender melhor semelhante transparência, semelhante submissão a um comando no seio do aberto, recorro a um exemplo maravilhoso oferecido pelo Frei Hermógenes Harada num comentário ao referido texto de Heidegger.

Vamos evocar uma experiência. Existem encontros nos quais nos sentimos humildes. P.ex. você encontra uma pessoa pobre, sem muito estudo, simples, talvez até marginalizada na sociedade. Digamos que ela é o empregado da sua firma que tem a função de varrer os büros. Sua linguagem é humilde, ela o trata de senhor, é serviçal. Você a trata como um João ninguém, impessoalmente, como o operário da sua firma, uma peça insignificante no conjunto da sua firma. Certo dia, você está de mau humor. E descarrega a sua irritação sobre o empregado. Você o humilha injustamente. O "pobre" homem não reage. Ele aceita a humilhação. Mas de súbito você percebe que ele, ao aceitar, não se avilta, não se torna servil, você sente nitidamente uma transparência nesse homem, uma grandeza humana: a dignidade. Há nele algo de superior, uma superioridade que não se eleva, humilhando-me nem me rebaixando, mas uma superioridade ontológica, que está simplesmente sendo, singelamente, como a rosa, que floresce sem porquê. E nessa transparência você sente um calor humano de compreensão. Ao aceitar a humilhação, o pobre me aceita não como "chefe", como "superior", mas como uma pessoa malhumorada, que precisa de compreensão do amigo. Há, nessa aceitação do pobre, algo de cordial, amor de simpatia, pela minha fraqueza, uma doação generosa que vem ao meu encontro, como serviço gratuito e livre à minha pessoa humana. E, de repente, compreendo o que é a humildade. A essência da humildade se me torna presente, se ad-presenta, se torna "objetiva", não como coisa, não como ideia abstrata, mas como "é manifesto" na concreção dessa pessoa. (HARADA, 2009, p.233)

O exemplo faz sobressair, por meio de um contraste seco, a diferença entre a prepotência do "empresário", do homem instruído, que regula tudo segundo a sua própria bitola de valores, que submete a realidade a seus projetos e ambições, e o poder humilde, discreto, do "pobre", que revela, justamente, uma superioridade ontológica por acolher uma medida, por submeter-se a um comando. Não, evidentemente, ao comando do "chefe" ou a um comando exterior qualquer, como seria, por exemplo, o mandamento de uma moral da resignação. O "pobre", para espanto do "chefe", nem reage e nem se rebaixa. Sua ação é discreta, recolhida, sem confrontação. Ele trata o "chefe" como uma pessoa mal-humorada necessitada de compreensão. Há em sua conduta uma aceitação, um acolhimento, que deixa ser: 


\section{Aoristo)))))}

International Journal of Phenomenology, Hermeneutics and Metaphysics

poder e liberdade. $\mathrm{O}$ poder é essencialmente uma abertura que acolhe. $\mathrm{O}$ homem "servil" e "insignificante" se revela agora, aos olhos do chefe, como superior. O "chefe" é trazido de volta a si graças ao sentimento de pudor. Já não é pura e simplesmente "chefe", contraposto a um outro que deve cumprir as suas ordens. Há um desprendimento, um acontecimento de compreensão. Harada chama esse poder livre, que nem rebaixa e nem se rebaixa, de humildade. O poder deixa livres aqueles que estão em sua esfera de manifestação. O poder serve, presta um serviço, não serviliza. No extremo da herança grega temos assim a sua manifestação como humildade, como deixar ser, como serviço. $\mathrm{O}$ "pobre" e não mais o "aristocrata", o senhor, seria o seu porta voz. Dialética do senhor e do escravo?

\section{REFERÊNCIAS}

ARENDT, Hannah. A condição humana. Trad. Roberto Raposo. Rio de Janeiro: Forense Universitária, 2009.

ARISTÓTELES. The Nicomachean Ethics. Translation by H. Rackham. London: Harvard University Press, 1999.

Ethica Nicomachea I 13 - III 8: Tratado da virtude moral. Trad. Marco Zingano. São Paulo:

Odysseus, 2008.

AUBENQUE, P. La prudence chez Aristote. Paris: Quadriage, 2002.

BRAGUE, Rémi. Introdução ao mundo grego: estudos de história da filosofia. Trad. Nicolás Nyimi Campanário. São Paulo: Loyola, 2007.

. Aristote et la question du monde: Essai sur le contexte cosmologique et anthropologique de

I'ontologie. Paris: Les Éditions du Cerf, 2009.

GADAMER, Hans-Georg. O caráter oculto da saúde. Trad. Antônio Luz Costa. Petrópolis: Vozes, 2011.

HAN, Byung-Chul. O que é poder? Trad. Gabriel Salvi Philipson. Petrópolis: Vozes, 2019.

HARADA, Frei Hermógenes. Iniciação à filosofia. Rio de Janeiro: Daimon, 2009.

HEIDEGGER, M. Marcas do caminho. Trad. Enio Paulo Giachini. Petrópolis: Vozes, 2008.

HEMINGWAY, Ernest. O velho e o mar. Trad. Fernando de Castro Ferrero. Rio de Janeiro: Civilização

Brasileira, 1981.

LORAUX, N. Invenção de Atenas. Trad. Lilian Valle. Rio de Janeiro: Ed. 34, 1994.

NUSSBAUM, Martha C. A fragilidade da bondade: Fortuna e ética na tragédia e na filosofia grega.

Trad. Aníbal Mari. São Paulo: Martins Fontes, 2009.

RIBEIRO, R.(org.) Política, direito e economia no século XXI: Anais do IV Encontro nacional de Filosofia Política Contemporânea. Rio de Janeiro: Via Verita, 2019.

TUCÍDIDES. História da Guerra do Peloponeso: Livro I - Edição bilíngue. Trad. Anna Amaral de Almeida Prado. São Paulo: Martins Fontes, 2013.

. História da Guerra do Peloponeso. Trad. Mário da Gama Kury. Brasília: Ed. UnB, 2001.

VERNANT, Jean-Pierre. Origens do pensamento grego. Trad. Manuela Torres. Lisboa: Teorema, 1987.

Submetido: 10 de janeíro de 2021

Aceito: 10 de fevereiro de 2021

Francisco Moraes

Toledo, v. $4, n^{\cdot} 1$ (2021) p. 78-91 